\title{
Os Manuscritos Literários: memória em processo
}

\author{
THE LITERARY MANUSCRIPT: MEMORY IN PROCESS
}

Lourival Holanda*

Resumo: Os manuscritos atestam um modo de memória e um processo criativo que dizem muito de um momento cultural. Simultaneamente memória social e mecanismo mental aqui se conjugam. O geneticista busca o fio complexo que liga a memória social à individual, no arranjo peculiar de que o manuscrito dá indícios, e os elementos esparsos que compõem a imprevisível lógica do manuscrito. Assim, os manuscritos permitem acompanhar a lógica de composição; o ato de criar, concernindo o texto literário; o silêncio inicial ao ritmo que a escritura persegue entre rasuras, hesitações, variantes e retomadas. A aposta do geneticista é a recolha de elementos que permitam ver o texto em ação - o manuscrito - a partir da detecção das descontinuidades do processo de escritura. Este processo criativo pode bem ser explicitado nos manuscritos de Graciliano Ramos, de Gustave Flaubert ou de Guimarães Rosa. O presente artigo busca mostrar o quanto o estudo dos manuscritos acrescenta à compreensão do texto final.

Palavras-chave: Manuscrito. Crítica genética. Processo de criação.

Abstract: The manuscripts attest a form of memory and a creative process
that say a lot about a cultural moment. Memory and mental mechanism here
combine simultaneously. The researcher seeks the complex thread which
connects social to individual memory in the particular arrangement that the
manuscript points out; and the scattered elements that compose the
unpredictable logic of the manuscript. Thus, the manuscripts enable us to

* Doutor em Língua e Literatura Francesa pela Universidade de São Paulo (1992). Professor Associado 1 - UFPE. Diretor da Editora Universitária da UFPE. Contato: lourival.holanda@gmail.com.br. 
follow the composition logic; the act of creating regarding the literary text; from the initial silence to the rhythm that the scripture chases among erasures, hesitations, variants and resumptions. The researcher bets on the collection of elements allowing him to see the text in action - the manuscript - from the detection of discontinuities in the writing process. This creative process can be well explained in the manuscripts of Graciliano Ramos, Gustave Flaubert or Guimarães Rosa. This article tries to show how manuscripts can help. in the meaning of the final text.

Keywords: Manuscripts. Genetic criticism. Creative process.

\section{Introdução: a memória amarga do século}

A crítica genética veio na esteira de um movimento de preocupação com a recuperação geral do acervo da memória social - sobretudo depois da quebra na continuidade de um modelo de cultura vigente até a Segunda Guerra. Consequentemente, começa na Europa, na Alemanha, com os manuscritos de Goethe, de Schiller, Novalis; na França, com os de Victor Hugo, os de Proust; desde a memória amarga do século XX, que se inaugurava contando seus mortos, à memória das coisas e de seu processo de criação. Houve, de fato, um crescente movimento voltado para a memória. Talvez isso diga muito, já, da dissolução do projeto de futuro, do desencanto com o presente. Um esvaziamento progressivo do futuro. O poeta anglo-americano H. W. Auden (2010, p. 248) dirá isso de modo certeiro e contundente:

\section{From Archaeology}

one moral, at least, may be drawn,

to wit, that all our school text-books lie.

What they call History

is nothing to vaunt of

being made, as it is,

by the criminal in us:

goodness is timeless. 
Portanto, o cuidado com os manuscritos vem num contexto duro: de quase derrocada das representações culturais. As turbulências teóricas e as flutuações ideológicas que atravessaram o entresséculo alargaram e aprofundaram as possibilidades de pesquisa dessa memória amarga. Apenas se reverte aqui o sintagma linear e cronológico, da memória social, pela verticalização do processo criativo. Em outro contexto, Quevedo lançou imagem aqui pertinente para ajudar a entender o trabalho do manuscrito - e seu distanciamento do texto enfim dado a público: Espejo convexo pero fiel- o crítico, no que busca, se busca. O começo do Em busca do tempo perdido surpreende o leitor: acabara de ler e parecia que era eu o assunto. Mais recentemente, Pascal Quignard reatualizará a lição quevediana: cada leitor busca ouvir vozes que recomponham sua infância. Cada qual projeta o eco das sereias que traz em si.

Tantos os manuscritos de Victor Hugo quanto os 950 documentos de Guimarães Rosa, resguardados no Acervo do IEB-USP; os 2500 fólios de Flaubert; os 75 cabiers de Proust; os manuscritos, também no Acervo do IEB-USP, onde se via formar a maneira de Graciliano Ramos; as versões de um romance no computador de Milton Hatoum representam Mil modos e um mesmo mistério: o do processo de criação. Fernando Pessoa havia intuído o mote: "Que parte de mim/ que eu desconheço/ é que me guia?" (PESSOA, 1998, p. 64). O primeiro movimento ia no sentido da preservação do acervo cultural. O que se segue, logo depois, buscava verticalizar e ver, não tanto o produto, mas o processo. Criar é traduzir: subentende, portanto, que não há imaculada concep̧ãa do texto literário: o texto advém sempre de um texto. Todo texto traz, subjacente, um outro texto que se deixa decifrar. E onde o escritor vai recifrar assim a tradição.

Volta a questão do sujeito - da escritura ou outro - que se define por ser um feixe de relações: a sociedade, a tradição, o momento histórico em que lhe coube estar. É, portanto, salutar repensar as aporias da conceituação psicanalítica, suas apostas e sua responsabilidade enquanto um saber cuja força vem da renovação, não de um peso doutrinal. A psicanálise deve ser um discurso vivo, dinâmico, pela natureza de seu próprio objeto: a psicanálise é a atividade de um sujeito enquanto sujeito para/com um sujeito enquanto sujeito. Algumas equivocações circunstanciais de Freud, no início, decorreram daqui. É a época das hipóteses orgânicas, quando carrega nos vocábulos cientificistas, 
fala em fatos constitucionais (A mecanismos preferimos hoje processos). Naturalmente, está num horizonte positivista que irá alargar depois. As posições de Freud avançam, desde o momento em que crê poder responder à histeria, à neurose obsessiva, aos distúrbios brabos, com química, até as proposições conceituais de 1939, quando Freud se rende à especificidade de sua atividade. É quando se dá conta que sequer a suposta fechada cientificidade vai exorcizar a dificuldade de inteligibilidade do fenômeno psíquico.

O sujeito especificamente da literatura traz uma particularidade: está assujeitado a uma língua [que é uma dada sensibilidade e visão de mundo]. É nesse sentido que Derrida desconstrói a autonomia suposta do sujeito ocidental, mas os escritores já vêm sinalizando isso desde longe: o ser misto, em Rousseau; os dois homens em mim, de Racine; o eu de agora e o eu de um quarto de hora atrás somos dois, como com graça está em Montaigne; ou ainda em Grande Sertão: Veredas: "O senhor vai ver. Eu era dois, diversos?” (ROSA, 1994, p. 311). Hoje, depois da contribuição considerável das ciências contemporâneas à complexidade do real, é mais fácil ver o sujeito - tanto o existencial como o escrevente - enquanto instância à beira do indecidível: haveria uma indeterminação fundamental nos procedimentos em estrutura micro.

A analogia com a indeterminação na origem dos processos criativos é tentadora - com risco, no entanto. O começo é proteico, aberto a algumas possibilidades. Mas, o verbo ser é de fato pobre, redutor, para dizer as possibilidades imprevisíveis do humano; decidir é etimologicamente cortar em meio aos possíveis, o real inédito. Riobaldo até então seguia sendo o homem de seu bando, com os usos e costumes, mas em face de Diadorim, há o apelo surdo do corpo, essa outra razão abrindo em sua vida derivas perigosas. Riobaldo ainda não sabe nada; seu corpo, sim: "Meu corpo gostava de Diadorim" (ROSA, 1994, p. 120). Mais adiante o narrador roseano, certeiro, diz: "Diadorim me veio, de meu não saber e querer" (ROSA, 1994, p. 200). Assim, o artista é tentado a trazer uma forma inédita, possível e ainda dispersa na cultura - que é o processo de criação; o novo arranjo é um salto cego. Há tensão no gesto criador. [Ironicamente, também pode não haver: quando alguém produz apenas para contentamento de seu público - e o mercado agradece e paga em cêntuplo]. 
A questão mais funda seria saber onde a gênese do texto toca a genealogia de um sentimento. A linguagem, instaurada onde começa o humano - e sua conformação societária, portanto, redutora já. A percepção e a elaboração secundária: a lógica da língua, a gramática, as regras do discurso. A liberdade da linguagem; e a gramática - que se opõe à lógica associativa do inconsciente; a linguagem surge de um surto de vida, uma insurgência. Mas, mesmo com a aventura de Mallarmé, sua liberdade está condicionada à última garantia: a sintaxe. Sem uma sintaxe, mesmo mínima, não haveria como comunicar, desfeitos os fios da conexão humana. Mas, há a linguagem, antes mesmo que um propósito. É assim, pois, que "todo um trabalho se faz em nós sem nosso consentimento [...] nosso estado consciente é um quarto que arrumam em nossa ausência”, diz Valéry (1988, p. 355).

É fácil perceber o ritmo da cultura contemporânea pelo andamento vertiginoso com que tudo se sucede. A velocidade das mudanças tecnológicas provocou um grande impacto nas concepções de memória, documentação, arquivamento, e também, e não menos, nos processos de criação - concebida como rearranjo singular de um material disponível - tudo convergindo, rápido, para o ciberespaço. $\mathrm{O}$ conceito de gestão da memória cultural resiste ao atual processo de reorganização na esfera pública virtual? Sobretudo porque os processos de retenção de memória têm sido eminentemente sociais. Alguns temem que a documentação perca sua autoridade - a relevância que até então marcou sua presença no corpo social. A enxurrada de material, entre documentos, fotos e textos que a mídia eletrônica propicia estaria desvalorizando o aporte simbólico anterior que capitalizava, através de um dado lugar de memória, um certo sentido social. A literatura, nos tempos atuais, vê-se mais marcadamente interpelada por outros códigos e outras interações discursivas e outros suportes: a da história, a dos estudos culturais, a da psicanálise - e mantém sua especificidade. Uma nova inteligência dos fatos sociais pede tais conexões. E estas, por sua vez, só são possíveis porque um modo, o código literário, as permite e pede, até, para aumentar os índices da profusão criativa do contemporâneo.

É pela reserva de memória que uma sociedade repropõe assim o sonho social. Quando esse imaginário social decai, há risco. De um lado, o da conformação em sua forma mais baixa: a renúncia ao real; do outro, o desastre social da aceitação da indiferença - que resulta na indiferença aos 
desastres sociais (Aquilo a que um jornal de São Paulo chamou recentemente a banalização que, quero crer, tem o sentido de vida sem solicitação). Por isso nunca é demais lembrar a responsabilidade dos professores de literatura, no momento que atravessamos, tão próximo da estagnação e do conformismo - como se o desgaste de uma utopia fizesse esquecer a permanência de sua necessidade. Apesar do desgaste advindo do descaso político com a função social do ensino, é preciso propor, contestar o consenso, reagir ao vale-tudo ideológico. Movimento pendular entre o inventário e a invenção. Uma sociedade precisa de seus espaços de memórias (claro: incluam-se aqui os grandes textos literários, os grandes romancistas; a eloquência das ruínas) para impedir a esclerose do corpo social. Um grande escritor é o repositório privilegiado da emanação memorial de sua época e, simultaneamente, seu adversário crítico, se pensarmos com Dostoievski que somos livres enquanto pudermos dizer não à resignação à realidade do apenas havido; fica a imantação forte do que poderia haver. Se uma sociedade se resigna, seja a de dimensão grupal, seja a nacional, sem mais a energia que emana da memória retrabalhada, que assim a impulsiona, pode cair num período de marasmo, de desencanto, análogo aos "buracos negros" da Física contemporânea: bebendo a vontade de vida, devorando a luz e a matéria que foi sua substância; deixando exangue o que foi, antes, a cultura, para dar lugar, pelo excesso de consumo, a um triste tédio - que é avesso do trágico; sobretudo na concepção grega onde Nietzsche vê o que o trágico traz de tônico.

A memória de que dá conta o manuscrito é a memória de um modo de cultura cujo eixo tem sido o texto - qualquer que fosse seu suporte: pedra, papiro, papel ou pendrive; e que supunha um trabalho duplo: um, na superfície da matéria, no ato mesmo da inscrição ou transfiguração do real em imagens verbais; e o outro, na laboração em sonda, em profundidade abissal, beirando a impossibilidade de dizer o que escapa, entre o que a instância escrevente mal sente e aquilo que ela apenas pressente poder sinalizar. $\mathrm{O}$ que resulta daqui bem pode ser um texto literário, diga-se: o que, pelo arranjo verbal singular acrescenta algo ao protocolo da linguagem. E temos, enfim, um auctor - retomando o étimo ainda resguardado em palavras como augmenter, aumentar, acrescentar. No manuscrito, a tensão comum a todo processo singular de criação: a síntese do disperso, na soma de possibilidade que convoca à / a forma. No vazio do tablado, a dança, os passos possíveis 
naquele espaço; na tela do computador, do smartphone, pululam possibilidades desde o teclado. No manuscrito, o tex to virtual, viável, possível; que se inaugura a passos de contradança: avança, repara, apara e por fim põe como textual - que só por desistência faz-se definitivo.

A luta com o anjo: as rasuras - o texto móvel; difícil de decidir, as tantas possibilidades - mas o texto quando sai vai mancando, boîteux; só se define mutilando-se. Os teóricos franceses falam, com muita propriedade em campagnes rédationelles: bela imagem bélica, que traduz o lugar de um embate, espaço agônico. Graciliano Ramos reconhece - e assim se define: "Sempre compusera lentamente; sucedia-me ficar diante da folha muitas horas, sem desvanecer a treva mental, buscando em vão agarrar algumas ideias, limpálas, vesti-las" (RAMOS, 1956, p. 93). Por isso importa tanto ao geneticista a ida ao manuscrito: ali estão traços de um embate do scriptor com a tradição, com a linguagem, com os valores da comunidade.

É o que permite apontar, no texto, as reverberações dos sismos sociais. A rede estilística detecta tipos de percepção - o momento em que o modo de ver dá a forma de sua representação. Daí a importância dos manuscritos que testemunham a formação de um estilo; no que o acesso à chambre des écritures permite detectar lutas e escolhas gracilianas (HOLANDA, 1992, p. 21).

O manuscrito é índice de uma vontade de rearranjo do mundo enquanto aposta de quem se propõe pôr, sobre o caos do mundo, uma ordem escritural.

Literatura é expressão e expansão do Imaginário porque ele tende a unir, a fazer uma sintaxe do caos do mundo. Como? Pela amarração da Leilinguagem. Aqui o Imaginário toca o Simbólico - e ele mexe-se, alarga-se. O Imaginário é um conjunto de forças que se inscrevem no Simbólico. Daí as instabilidades. Porque ele vai contra o Real - que toma forma na escritura literária. O sujeito se constitui na ordem simbólica (Fabiano, em Vidas Secas, poderia configurar isso). Mas ela é fonte de neuroses: de divisão entre o Imaginário (de Sinhá Vitória) e aquilo a que o simbólico obriga e submete. Sinhá Vitória, como cada qual, forma suas representações em função de seus desejos. A sociedade, idem. A totemização de certezas supostas se opõe a 
isso. Daqui, também a "utopia": Fabiano sai - Fuga - mas agora tem maior domínio de si. Mudança: que supõe projeto. As conversas com Sinhá Vitória, com seu Tomás, liberam o imaginário de Fabiano. É só depois que é levado ao distanciamento que permite ver o Soldado enquanto mero agente da Lei. Reduz o que superdimensionou: pode, portanto, lutar com ele. Certamente, assim com as redações sucessivas, as rasuras: o scriptor sai de seu fascínio e agora luta por dizer-se. O confronto de Fabiano com o Soldado Amarelo serve de analogia à posição do escritor frente às convenções da linguagem. Dentro do consenso da linguagem não se cria, se repete. Criar é sempre arriscar-se: ao desconforto, ao descontentamento:

Programa e impasse. Enfrentar a infração ao código literário acua o escritor entre o sistema e sua própria singularidade. Daqui decorre a tensão do texto Graciliano: pôr, nos moldes da forma/fôrma da ordem, as marcas de sua individualidade (HOLANDA, 1992, p. 22).

Os meninos percebem o hiato entre o fascínio da palavra inferno e seu sentido a esconjurar. Mallarmé não atravessou o Sertão - e as palavras continuam reféns de seus referentes. Há ainda, ali, um fascínio pela palavra e certa reserva sertaneja.

\section{Os Meandros do Manuscrito}

Os manuscritos dão pistas de um processo criativo - que também traduz uma atitude frente à linguagem: o fascínio de Euclides da Cunha pela palavra; a admiração e receio por esse fascínio, em Graciliano Ramos (Words mean what I want them to mean - diz o arbitrário Humpty Dumpty, nas maravilhas verbais do País de Alice). No consenso social - sobretudo político - a palavra de ordem precisa ser repetida; não há criação no consenso. Daí porque é só no dissenso que se inventa, que se cria. Com seus riscos,

aqueles dos quais bem pouco sabe o escritor ao empreendê-los e ao longo do qual, arduamente, avança e descobre, revela, devassa territórios que desconhecia, podendo suceder-lhe, durante a realização da obra, chegar a evidências e surpresas que lhe ameaçam os alicerces da vida (LINS, 1979, p. 19). 
O narrador graciliano, com suas variações, traz esse fascínio pela linguagem. É curioso como tantos escrevem, entre os personagens de Graciliano. Padilha escreve, Madalena escreve; mesmo Paulo Honório (em São Bernardo), que vai xingá-los por escrever, finda escrevendo. Parecem sentir como impasse e urgência a necessidade dessa mediação torta entre o mundo e o sujeito. Fabiano, na procuração [a ambiguidade aqui serve em dobro] da palavra de Seu Tomás da Bolandeira; os meninos, na fala do pai, com seus hiatos - que os fazem mais imaginar; na palavra de Sinhá Terta ("Sinhá Terta é que explicava como gente da rua”) (RAMOS, 1986, p. 16). Fabiano admira as deduções surpreendentes da linguagem de Sinhá Vitória, os links que ela é capaz de fazer. "As palavras de Sinhá Vitória encantaram-no. Iriam para adiante, alcançariam uma terra desconhecida" (RAMOS, 1986, p. 16). É pela fabulação que Fabiano se salva do impasse do presente. Desejo do verbo, num primeiro movimento, e esse verbo cria, instiga. $O$ desejo dilata a expectação em sua postulação ( $O$ tempo verbal já metaforiza, metonimicamente, a postulação literária: o futuro do pretérito - onde prevalece a aposta, o futuro, a expectação; a observação hegeliana é certeira: o anúncio importa mais que a memória. Portanto, Fabiano sabe, intui, quando avança).

Em dado momento Espinosa expõe o dilema do escrevente: precisa optar, ter a coragem de arbitrar - omnis determinatio est negatio. No que uma escolha redacional supõe denegação de outras, possíveis. O escritor luta com/ contra a língua; o crítico, com a mobilidade do texto [qual considerar?] e suas pistas [por onde?] - embates sem final [qui n'aboutit pas: luta nunca conclusiva, como diz Philippe Willemart]. Dobrada luta: partir do tesouro comum [a língua] e perseguir a singularidade de um imaginário irredutível, aí. O que nos remete ao parágrafo 16 do Da interpretação onde Aristóteles pensa o peso do sentido social que as palavras adquirem: é contra ele que o manuscrito testemunha - e mostra as marcas da criação. O kata synteken, na precisa expressão grega - aquilo que é socialmente instituído. O valor dos manuscritos: ali se persegue um movimento contra o consensual; um arranjo singular colhendo elementos dispersos da linguagem. Ainda nos manuscritos de Graciliano Ramos não é difícil detectar o movimento de desbaste, de redução do volume da frase à sua estrutura semântica mais propositadamente musical. A busca do ritmo, evidenciada nos manuscritos de Graciliano, nos de Gustave Flaubert ou Guimarães Rosa, indiciam a linguagem no processo de 
tornar-se literatura. Nos manuscritos, o processo de desbaste que fica como emblemático na construção da frase graciliana:

Sinhá Vitória acomodou os filhos que [se] arriaram no chão como trouxas, cobrindo-os com molambos [que retirou do baú]. O menino mais velho [tinha se reconstituído da] passada a vertigem que o derrubara [no caminho] [agarrou] encolhido sobre folhas secas, a cabeça encostada a uma raiz, adormecia, acordava (RAMOS, 1969, p. 12).

Em colchetes os termos expurgados. Em dado momento do manuscrito está: "Os juazeiros aproximaram-se e afastaram-se a uma volta do caminho recuaram, sumiram-se." Quando enfim o texto é entregue, resolve-se na gradação três verbos simétricos: "Os juazeiros aproximaram-se, recuaram, sumiram-se". Também é essa música, o ritmo de frase que encontramos em Rosa: "Arreamos, montamos, saímos" (ROSA, 1994, p. 184). Ambos os escritores têm diapasão que cada qual ajusta a seu modo, mas o cuidado com o ritmo, com a música da frase parece ser uma invariante do texto literário que compõem. $\mathrm{O}$ trabalho com os manuscritos permite perceber esse ritmo buscado: "deixaram a margem do rio [foram beirando a cerca], acompanharam a cerca, subiram uma ladeira e chegaram e chegaram aos juazeiros" (ROSA, 1994, p. 184). A frase se resolve em quatro membros simétricos que escandem um movimento de crescendo.

A escritura usa o escritor: finda por fazê-lo dizer mais [que o pretendido]. Por ceder a iniciativa às palavras, mobilizadas pelo choque de suas desigualdades. São os significantes que balançam o leitor (mais que a intenção do escritor). Tal balanço acorda coisas dormidas... A grande literatura condensa significações e sentidos no modo incomum: o poético. E o poético, como o simbólico, diz sempre uma palavra oblíqua. Uma cadeia de significantes que se supõe circunscrever o significado primevo, ausente. $\mathrm{O}$ analista buscará o saber desconhecido ali cifrado, a verdade do inconsciente que faz sua aparição através do significante. O escritor se define por ceder a iniciativa às palavras, mobilizadas pelo choque de sua imprevisibilidade. São os significantes que balançam o leitor (mais que a intenção do escritor). Tal balanço acorda coisas dormidas; insabidas; ou apenas pressentidas. "As prisões que estão 
refincadas no vago, na gente" (ROSA, 1994, p. 203). O escritor, com antenas atentas, capta e cripta $o$ encoberto e o esquecido. Coisas que, no entanto, subjazem no impensado da língua.

O geneticista - lendo além da superfície, em sonda, endoscopiando o que subjaz no texto - vai surpreender-se ou extasiar-se com essa feitiçaria evocatória do verbo, que alarga as possibilidades de dizer-se de uma cultura e desdobra as dimensões do homem: o que talvez defina a literatura. Há, portanto, na estruturação do discurso poético uma reversão da sintaxe lógicodiscursiva que pede um outro modo de abordagem. A prática analítica em filosofia ou a crítica literária trabalham, ambas, enquanto descodificadores semióticos. Algumas vezes a reconstituição da memória cultural se dá pela restituição do textual: até a edição 1983, de Vidas secas, da Editora Record, escapava um descuido: "uma aragem morna acudia os xiquexiques e os mandacarus" - quando os manuscritos confirmando o bom senso trazem: "uma aragem morna sacudia" (ROSA, 1983, p. 4). Para não ir muito longe, ainda aqui, há um bom índice modal do processo de criação em Graciliano: à margem do manuscrito ficam algumas palavras como que pairando no ar pedindo pouso: "a lua estava enorme, redonda". Pouco adiante o núcleo, desenvolvido, reaparece: "A lua crescia, a sombra leitosa crescia, as estrelas foram esmorecerendo naquela brancura que enchia a noite" (RAMOS, 1983, p. 16).

No que Benveniste tem toda razão: o ponto de partida da análise é o mesmo da literatura: as aventuras com o verbo, as figuras retóricas, as figuras de linguagem. O inconsciente sutilmente converte metaforicamente os símbolos, tira partido deles. Aí pode estar seu sentido - e sua dificuldade. Há um vivido inicial que deita traços - ainda que esses sejam também sonhados - a dura administração de nossas ausências - como reivindica Baudelaire; vestígios mnésicos - portanto, pessoais, ancorados na alma - com que trabalha o escrevente. Em algum momento de nossa vida o impacto de certas coisas nos marca - e muito tempo ainda essa memória em nós sangra. Manuscritos são papéis com as nódoas que constituem o sujeito. Os manuscritos mostram quanto os textos devem ao acaso, aos caprichos e às paixões.

Mas, estes são os vestígios materiais com que trabalha o geneticista, quando busca documentos, sinais deixados nas ruínas, no esboço do texto, e tenta recompor, no relato, o sentido que o habitou. Assim, também o corpo 
social cria, para o tempo, uma memória que o sagra. Uma palavra deixada na margem do texto, uma observação apenas apontada - e o geneticista, ao avançar em sua perquirição, recebe o choque de um achado, a gênese de um texto depois desenvolvido; no manuscrito, apenas vislumbres de uma atração verbal potencial, ali resguardado em forma de esboço, numa primeira redação. Daí a importância da recorrência à memória que guardam os manuscritos e as consequências antropológicas perturbadoras resultante da negligência com este acervo. Contaminação progressiva do ritmo do imediato sobre o ritmo da memória.

Quando, depois de 1907, a pesquisa freudiana se volta para a Gradiva, de Jensen, ele quer ter uma posição-chave sobre uma interpretação da cultura, de grande abrangência, e escolhe então a literatura. Na época, ainda, a literatura era enformadora - e formadora de opinião (Papel passado à Igreja, de início, depois às Universidades e hoje, enfim, deixado à Mídia. Literatura era ainda o espaço do diálogo socrático de nosso tempo. Ali se viam as possibilidades e as razões que faziam agir o homem). Freud intui, portanto, ali, o espaço onde se inscreve o desejo latente e esse processo de dissimulação e revelação. A psicanálise ganhava um campo vasto, e a literatura, um modo hermenêutico de leitura. Numa homenagem prestada aos seus 70 anos, um orador louvou Freud enquanto descobridor do inconsciente. Honesto, Freud ratifica: "Os poetas e os filósofos descobriram o inconsciente bem antes de mim; o que descobri foi um método científico que permite estudar o inconsciente" (TRILLING, 2015, p. 63). Freud reconhece o débito com os poetas e com os filósofos gregos assim como com Schopenhauer, de onde certamente reteve a sugestão da imagem do Édipo, como diz em carta a um amigo, mais tarde.

Literatura é essa perda de certeza, essa deriva. Não abarca as coisas, tangencia-as. "Contar seguido, alinhavado, só mesmo sendo as coisas de rasa importância”. Para dizer com Lacan, seu sentido fica às bordas ou transborda. Entre o literal e o litoral. "A razão de coisa nenhuma não é verdadeira, não maneja” (ROSA, 1994, p. 226). A linguagem simula a astúcia do desejo - e esse segue a curva assintótica, sem tocar diretamente seu objeto. A linguagem age no modo oblíquo. O poeta contrapõe ao suposto saber, um saber insuspeitado: "A gente só sabe bem aquilo que não entende" (ROSA, 1994, p. 286). Trata-se aqui de um outro percurso, à cata do desejo, da falta, 
ocultados no entredito. Lacan alarga a leitura psicanalítica quando dá prioridade à cadeia de significantes, antes que a um suposto significado prévio. Grande Sertão: Veredas, tendo embora todo um percurso épico é, sobretudo, um grande texto lírico: uma metáfora continuada de um sentimento único. É o espaço de uma falta, a que a linguagem busca paliar, criando um gozo supletivo. Multa petentibus, desunt multa, diz Ovídio: muito desejo é sinal de muita carência. Signo e sentimento, como diz o narrador.

Daí a leitura do poema surrealista: mais que um modo de representação tópico, conta aqui outra dinâmica - associativa. Daqui o risco esquizofrênico: de desligar, completo, a expressão verbal da coisa, e apenas jogar com os significantes. No entanto, mesmo os manuscritos dos surrealistas [guardados no Item, de Paris] não deixam dúvida: há elaboração, há um trabalho com o ritmo, como busca de um espaço por onde escapar da incomunicação pela disposição rítmica, corporal, e pelas regras do processo musical. Poesia é linguagem que se serve do ritmo do corpo, a escansão é um exercício do diafragma; prazer do corpo respirante num certo ritmo; do ouvido captando certa melodia; a escansão medindo o fôlego. Nesse sentido Galáxias, de Haroldo de Campos foi exemplar. Ou o Avalovara, de Osman Lins: gozo, mais que prazer, porque suspende o consenso da linearidade narrativa e transpõe o cotidiano para inquirições inquietantes.

Num estudo sobre Dostoievski, Freud fala sobre o fascínio de estudar as leis do psiquismo em indivíduos excepcionais. Fascínio e risco: quando subdivide a personalidade do russo, poeta, moralista, neurótico, pecador, diz sobre este: infelizmente diante do poeta o analista deve baixar as armas. Misto de homenagem e honestidade. Freud se distancia do literário porque, por propósito, quer um discurso científico - condição para ser ouvido por seus pares (Curioso: encontramos a mesma negociação na escrita de Euclides da Cunha, trazendo para a Rua do Ouvidor o áspero sotaque do sertão. Escritura pendular, entre o rigor conceitual perseguido e o vigor verbal evidente. Fato que faz pensar a força da linguagem agindo em alguns pesquisadores, para além do propósito circunstancial. Freud recebe reconhecimento, em 1930, por qualidades literárias. Assim também Gilberto Freyre: menor, se visto apenas pelas viseiras ideológicas; enorme, se pela visão que as sutilezas da linguagem permitiram perceber nos meandros da cultura. Euclides permanece maior que suas limitações supostamente científicas. A impregnação literária 
torna-os fecundos. Infelizmente não toca a tantos - a quem a literatura possuiu, mas não fecundou: escrevem cansando quem leia ). Controle experimental suposto, que se quer submetido à medida, num discurso científico. Mas, como, se aqui se trata de matéria móvel, uma linguagem não quantificável? Freud crê, em parte, brevemente poder suplantar, superar tal dificuldade criando uma linguagem quantificável, como a da química, por exemplo. Desde Newton, até as resistências de Einstein, a ciência apostou no modelo do domínio, do quantificável; com as ciências contemporâneas, as teorias recentes, das dissipativas, de Prigogine, aos fractais, mudamos de atitude, aprendemos humildade, sabemos que os fenômenos não seguem todos e necessariamente uma mesma ordem; assim a ordem de criação - de que os manuscritos dão conta. Assim, o novo modo de investigar, nas ciências contemporâneas, também serviu para alargar a compreensão do processo de criação de que os manuscritos dão conta: as instabilidades dinâmicas, ainda seguindo Prigogine (1966, p. 40).

\section{Manuscritos: memória de um processo}

O processo de construção do texto - memória, movimento do desejo e o gozo da letra - é dado logo de entrada, em Grande Sertão: Veredas. Um narrador reconstrói o labirinto das lembranças em busca de uma saída - um sentido costurando os surpreendentes pontos soltos do viver. Riobaldo conta, presta conta e dá-se conta de umas tantas vivências densas. Tal processo de rememorização que o poético efetiva, tem um chão comum: a linguagem. $\mathrm{E}$ seus embustes. E carece de um interlocutor, como em toda fala analítica. "No que narrei, o senhor talvez ache mais que eu, a minha verdade" (ROSA, 1994. p. 38). O que conta aqui não é redizer o fato, mas perseguir sua percussão, vida a fora. Como o analista, Riobaldo quer decifrar. "Eu queria decifrar as coisas que são importantes". Sabe que não deve esquecer porque o inventário é condição para a invenção: "Não gosto de me esquecer de coisa nenhuma. Esquecer, para mim, é quase igual a perder dinheiro" (ROSA, 1994 p. 260). Em um outro momento, outro narrador roseano havia dito: "Mas há, vaga, na gente, vontade de não saber, de furtar-nos ao malesquecimento. O inferno é uma escondida recordação" (ROSA, 1994, p. 1071). Freud não teria dito melhor. E tanto mais que, em dado momento de Grande Sertão: Veredas, o 
diabo é visto como o Ocultador (Seguindo essa figuração, o analista seria seu oposto, angelical?). Daí a importância, na velocidade vertiginosa como que agora sucedem as coisas, de balizar a cultura com as referências memoriais: o manuscrito, um modo de memória, um procedimento criativo.

Antes, muita tinta, e agora ainda tanta tecla se tem batido sobre a questão do sujeito, a instância escrevente. Ele está, de fato, assujeitado: a) ao modo de ser de sua comunidade - de que só a custo e em parte, se safa; b) assujeitado à estrutura da língua que condiciona seu modo de ver o mundo; c) e está estreitamente atrelado a seu corpo - singularidade definidora e inegociável: cada qual vai ser o que puder, mas vai, sempre, sentir como é. A lição espinosiana é de uma clareza meridiana: no que pensamos há muito de corpo, do corpo de cada qual, pelas pulsões ancoradas aí.

Certa vulgata freudiana prestou desserviço à causa quando quis reduzir o aporte analítico à normalização convencional. No entanto, aqui ainda a prática analítica alarga a leitura da nossa singularidade - como reivindicação. E estamos em plena literatura. Ao efeito surpresa que o aparecimento do inconsciente causa, corresponde o estranhamento que cria a linguagem, o modo literário. "Sou diferente de todo o mundo". Dupla estranheza; a de quem se sabe diferente; e que precisa dizer e marcar essa diferença num modo peculiar. "Eu sou é eu mesmo". "Divêrjo de todo o mundo". Sempre é a literatura a melhor epistemologia das ciências. Ela avança, já, o que as ciências soft agora reivindicam: o improvável, o apenas perceptível, o singular. "Então, eu era diferente de todos ali. Era. Susto disso - como me divulguei" (ROSA, 1994 p. 361). Em cada manuscrito se delineia um processo de criação único.

O narrador roseano parece oferecer a Freud as palavras a sua reelaboração do mecanismo psíquico como algo não estático, mas plástico, dinâmico. Em outro momento, Guimarães Rosa, num surpreendente lance de lince freudiano afirma:

Na própria precisão com que outras passagens lembradas se oferecem, de entre impressões confusas, talvez se agite a maligna astúcia da porção escura de nós mesmos, que tenta incompreensivelmente enganar-nos, ou, pelo menos, retardar que perscrutemos qualquer verdade (ROSA, 1994, p. 424). 
Aqui, também Guimarães Rosa, como Proust, explicita uma percepção que tangencia o viés freudiano: "Poetas e romancistas são para nós aliados preciosos, e seu testemunho deve ser altamente valorizado porque conhecem entre céu e terra coisa que nossa sabedoria escolar nem poderia sonhar" (FREUD, 1972, p. 35).

O sujeito é, assim, um feixe de relações - longe da pretensa autonomia total suposta pela concepção clássica, o homem sempre senhor de seus atos. A neurobiologia desdoura essa pretensão e, curiosamente convida a reencontrar a noção antiga da ananké grega: as necessidades fundas que nos movem; algo como um desejo - que se prefigura antes da vontade: será por isso que nasce um manuscrito, um projeto, uma surda vontade de forma? E tal vontade de forma se traduz, sobretudo, pela vontade de ritmo, a pulsão fônica, a música da palavra (WILLEMART, 2014, p. 9).

Somos a soma de nossos desejos. O mais, o que está aí, é contingência. Não somos sempre o que somos, principalmente. Representamos, e a isso chamamos socialização. A aposta literária é a de dar a ler o real verdadeiro que nos constitui. Carecemos do outro porque é desumano ser só. O analista ou o Deus de Jó: partilhar o peso do mistério que somos. "Conto ao senhor o que eu sei e o senhor não sabe; mas principal quero contar é o que não sei se sei e que pode ser que o senhor saiba". No mais das vezes o que ocultamos é o que nos complementa. "Quem muito se evita, se convive" (ROSA, 1994, p. 11). E esse será um mote recorrente: "A gente sabe mais de um homem, é aquilo que ele esconde” (ROSA, 1994, p. 216-217).

O geneticista e sua redobrada surpresa. Surpresa que paga em prazer. De descoberta. Atenção às camadas de redação - que nem sempre se sucedem: algumas ficam ali, nas margens do texto, enquanto um atrator de possibilidades. O geneticista, que Philippe Willemart exemplifica bem, é tentado a fazer analogia com o sistema dinâmico na Física contemporânea, que independe do ponto de partida. Uma palavra anotada à margem do manuscrito de Flaubert - e que ele só vai desenvolver três ou quatro páginas depois. Quando o matemático Henri Poincaré fez alusão a essas possibilidades, aos sistemas dinâmicos não lineares, aquilo pareceu contrário ao senso comum matemático. No entanto, é possível pressentir fenômenos assim com a flutuação contínua no repertório semântico de um escritor. Fenômenos de estrutura sistêmica simples são susceptíveis de uma dinâmica complexa. 
Novalis terá pressentido isso quando definiu aquele que escreve como alguém movido pela linguagem? [Sprachbegeistert]. É assim que Euclides da Cunha, tendo ouvido circunstancialmente, entre amigos, uma palavra que o toca, e não dispondo de papel, a escreve no punbo da camisa. Se no filósofo prevalece a ideia, no escritor o fascínio pela palavra. Com toda a carga implosiva que o significante carrega: indice do que sequer supomos saber, mas que a linguagem aponta sem dizer, como o recado de Delfos.

$O$ outro labirinto: o da perda das certezas. "Se a vida coisas assim às horas arranja, então que segurança de si é que a gente tem?” (ROSA, 1994, p. 307). O da perda do centro - que antes fazia o peso, o sentido, o sujeito. Hoje, o sujeito está em dissolução e disseminação. Já sabemos que somos relativos, finitos e indeterminados, como poeticamente diz Einstein. Na dicção roseana: "A vida é muito discordada" (ROSA, 1994, p. 307). Perde-se o paradigma linear: "A vida é um vago variado" (ROSA, 1994, p. 309) - e a segurança suposta da consistência do existir. Em muitos momentos o geneticista, como o escrevente, partem ambos da mesma pulsão no intuito de recifrar a complexidade do real na tentativa de torná-lo mais inteligível. Rosa diz: "vivemos de modo incorrigível, distraídos das coisas mais importantes” (ROSA, 1994, p. 151). A análise é essa moral da atenção ao real suceder interno e entorno: "Quando nada acontece, há um milagre que não estamos vendo” (ROSA, 1994, p. 476).

O trabalho do analista vem depois da primeira leitura: tenta subtrair, à contingência do cego suceder, seu sentido. Foi o que depois entendi vasto. Sentido ocultado, por alguma astúcia. Ou esquecido, por alguma interna necessidade. É justamente o que escapava à ambição do discurso positivizante. Os intelectuais cedo passam da adoração ao perjuro, quanto à razão. Cedo cedem aos sucedâneos quiméricos, às suplências simples - que tampouco cumulam as carências fundas de que somos feitos. Um paradigma mais sintonizado com o nosso tempo reverte esse jogo: é a astúcia do desejo - mais que a força da razão positiva - o que secretamente move o escritor. Qual, não se sabe ao certo: "Pelejar por exato dá erro contra a gente" (ROSA, 1994, p. 59). Voltando ao começo, podemos dizer, com Freud, que a essência do texto literário fica, para nós, psicanaliticamente inacessível. Não, porém, a inquietante estranheza da feitiçaria evocatória do verbo - que provoca, invoca, convoca o Outro latente no texto. 
O manuscrito é memória de um processo escritural. E, qualquer que seja o suporte, da pedra ao papiro, do papel ao pendrive, sempre haverá esse gesto, esse movimento de inscrição transfigurante do real em traços, tons ou textos - enfim, a criação. Há como seguir pesquisando os percalços do processo criativo nos suportes híbridos: texto, imagem, movimento, som. Alguns dos nossos teóricos recebem isso com lucidez, onde a acolhida às novas (?) mídias, não negligencia o rigor. Sérgio Luiz Bellei ou Alckmar Santos percebem modos de criar cruzando técnicas variadas (outros sistemas de dispor de um material criativo, memória e arquivamento tomando uma dinâmica inovadora; o presente experimental) e noção mais larga e includente de cultura (tempo longo; o das antologias, dos pertencimentos, dos ritos).

$\mathrm{Na}$ vertigem das mudanças contemporâneas a democratização dos suportes de criação e comunicação leva a redefinir muitos dos antigos valores. Os manuscritos de computador - porque é ainda a mão que tecla - faz ver, através da mudança, a permanência de um princípio. "As duas mais importantes revoluções relacionadas aos suportes que permitem armazenar, transmitir e receber a informação referiam-se à escrita" (SERRES, 2003, p. 226). Mas, a terceira, essa de que dispomos agora, vídeos, internet, Youtube, recupera a palavra e a escrita, em síntese surpreendente e renovadora. A criação acresce, e assim perturba a ordem anterior no que é a comum/unidade: comunidade é um processo homogeneizador; não há adequação social sem mutilação de si, sendo sempre à custa de alguma singularidade. É possível inferir dos manuscritos agonia e gozo do processo escritural. Como a crer que se bendigo ou maldigo, isso me minora o mal. E todo o jogo escritural passa por aí - tal no episódio em Festa [Vidas secas]: quando Fabiano, insultado, procura a palavra para xingar os soldados. Instantes depois a encontra e com visível satisfação: Descoberta a expressão teimosa, alegrou-se. Literatura bem pode ser vista enquanto empenho numa empresa de insurgência contra o real. E então, tanto do ponto de vista social ela é uma reserva de significados sociais.

Correções, rasuras, reinscrições: no arranjo das palavras, um rearranjo do mundo. Os manuscritos atestam experimentações, tateios, inaugurações, crendo que as estruturas mais fecundas nascem mesmo é dos pequenos desvios, das bifurcações, das mutações. A conformação, a tendência homogeneizante, enfim, os meios uniformes sendo sem energia. Sobretudo 
porque aceitar a realidade, sofrê-la passivamente seria uma forma demasiado inferior de renúncia. Para o pesquisador, especialmente para o geneticista, os manuscritos expõem um momento da cultura: o da vontade de forma. O geneticista trabalha os índices de um processo; será sua luta com o Anjo: pela compreensão? Philippe Willemart pretende apenas apresentar uma interpretação inédita (WILLEMART, 2014, p. 217). Atribui ao crítico a mesma posição do autor: simultaneamente Jacó e Anjo? Um segue, cego, sua pulsão; o outro pretendendo aclará-la, querendo tornar inteligível todo o real do texto - ils n'aboutissent pas, reconhece. Porém, esse é um fracasso luminoso - porque deixa em aberto o trabalho do imaginário do pesquisador, esse leitor municiado por uma frequentação a que o tempo torna atenta, descobridora.

O exercício crítico traz um limite no tempo e uma marca: a da interrogação convocante que alarga o objeto. Ele pressente haver entre rascunhos, lacunas e reinscrições uma ausência que não é propriamente privação, mas possibilidade de uma presença: o real apenas suposto. Podemos entender o Fernando Pessoa de "cada palavra dita é voz de um morto". [Poema inédito, manuscrito de 1918, que o poeta e colecionador Paulo Cavalcante adquiriu recentemente: “Toda palavra dita é a voz de um morto/ aniquilou-se quem se não velou. Quem, na voz, não em si, viveu absorto”]. O que vive na alma sempre sofre violência ao passar pelo crivo limitante da linguagem; morre, em parte. Proust havia intuído isso:

tout ce résidu réel que nous sommes obligés de garder pour nous-mêmes, que la causerie ne peut transmettre même de l'ami à l'ami, du maître au disciple, de l'amant à la maîtresse, cet ineffable qui différencie qualitativement ce que chacun a senti et qu'il est obligé de laisser au seuil des phrases où il ne peut communiquer avec autrui qu'en se limitant à des points extérieurs communs à tous et sans intérêt (PROUST, 1922, p. 257).

O geneticista persegue o real da escritura - algo de inominado; móvel como a matéria subatômica - de que não se pode descrever, simultaneamente, o peso e o lugar. O encoberto e o esquecido a que alude Guimarães Rosa? E que também se alça em dever de memória, em Graciliano Ramos, do cárcere às 
limitações a que nos constrangem as tábuas estreitas da gramática social. Alargar a memória é alargar os possíveis; permitir um futuro a uma sociedade que tenha o que antepor ao marasmo cultural, reivindicando ser simultaneamente esperançosa e reflexiva.

\section{Referências}

BONNET, C. Glen W. Bowersock. From Gibbon to Auden. Essays on the classical tradition. Anabases, v. 12, p. 245-248, 2010.

BELLEI, S. L. P. O livro, a literatura e o computador. São Paulo: Educ; Florianópolis: UFSC, 2002.

FREUD, S. A interpretação dos sonhos. O.C. Rio de Janeiro: Imago, 1972.

FREUD, S. Le delire et les rêves dans la Gradiva, de W. Jensen. Paris: PUF, 2010.

HOLANDA, L. Sob o signo do silêncio. São: EDUSP, 1992.

LINS, O. Guerra sem testemunha. São Paulo: Ática, 1974.

PESSOA, F. Obra poética. Rio de Janeiro: Nova Aguilar, 1987.

PRIGOGINE, I. O fim das certezas. Tempo, caos e as leis da natureza. São Paulo: Unesp, 1996.

PROUST, M. La prisonnière. Paris: Gallimard. 1922.

QUIGNARD, P. Le nom sur le bout de la langue. Paris: Gallimard, 1993.

RAMOS, G. Memórias do cárcere I. Rio de Janeiro: José Olympio, 1956.

RAMOS, G. Manuscritos de Vidas secas. Acervo IEB, USP, 1969.

RAMOS, G. Vidas secas. São Paulo: Record, 1983.

RAMOS, G. Ficção completa. Rio de Janeiro: Nova Aguilar, 1994.

SERRES, M. Hominescências. Rio: Bertrand Brasil, 2003. 
TRILLING, L. Freud e a literatura. In: TRILLING, L. A imaginação liberal. São Paulo: É Realizações, 2015. p. 63-88.

VALERY, P. Cahiers. II. Paris: Gallimard, 1988. (Organização de Nicole Ceylerette-Pietri e Judith Robinson-Valéry).

WILLEMART, P. Psicanálise e teoria literária. São Paulo: Perspectiva, 2014.

Enviado em: 03/11/2016

Aceito em: 10/12/2016 